\title{
Modelling the Hydrogeochemical Evolution of Mine Water in a Decommissioned Opencast Coal Mine
}

\author{
Altus Huisamen ${ }^{1,2}$, Christian Wolkersdorfer ${ }^{3,4}$ \\ ${ }^{1}$ Geo Pollution Technologies Gauteng (Pty) Ltd, (+27) 12804 8120, (+27) 128048140 \\ altus@gptglobal.com \\ ${ }^{2}$ University of Pretoria, Lynnwood Rd., Pretoria, South Africa \\ ${ }^{3}$ Tshwane University of Technology, Private Bag X680, Pretoria 0001, South Africa, \\ christian@wolkersdorfer.info \\ ${ }^{4}$ Lappeenranta University of Technology, Laboratory of Green Chemistry, Sammonkatu 12, 50130 Mikkeli, \\ Finland
}

\section{Highlights}

- Kinetic geochemical modelling calibration method proposed-calibration against leaching test data was successful.

- Transient source term transport modelling successful - calibrated against existing groundwater monitoring data.

- Improved confidence in numerical transport modelling of the initial flush from opencast mines

- Contaminant plume calibration in numerical models is possible using the proposed methodology.

\begin{abstract}
A method for the geochemical modelling of transient contaminant release from rehabilitated opencast coal mines, including calibration against existing data, is proposed. The need for such a methodology is illustrated by a directive received by a decommissioned opencast coal mine in Mpumalanga, South Africa. Groundwater monitoring data, geochemical analyses, numerical flow modelling and geochemical modelling are used to model the hydrogeochemical evolution of mine water over time. Models presented in this study are based on a conceptual model detailing groundwater levels and flow directions, hydraulic conductivities, groundwater chemistry, precipitation, evaporation, surface water bodies and potential sources. Additional to this, mineralogical analyses, leaching tests and acid-base accounting were performed to obtain a better understanding of the site geochemistry. A geochemical model was constructed which was used to obtain a statistically representative mineral assemblage based on laboratory data which was calibrated against leaching test data. This assemblage was simulated in field conditions as input to a numerical flow and transport model. The transport of sulfate was modelled accordingly and sulfate concentrations from monitoring data were used for chemical calibration. Following this, long term contaminant release was simulated. Calibration graphs from the transport model indicated concentrations within a $20 \mathrm{mg} / \mathrm{L}$ error margin, showing that the proposed methodology can be used to calculate contaminant concentrations in an aquifer over time within an acceptable range. This approach could provide an improved estimate of the duration of the first flush
\end{abstract}


which, upon completion, will transform decommissioned collieries into large scale reservoirs of utilisable groundwater.

Key words: Mine Water, Opencast mining, Hydrogeochemistry, Modelling

\section{Introduction and Previous Investigations on Mine Flooding}

With coal resources steadily becoming depleted, opencast coal mines in South Africa will approach a period of mass closure, inevitably impacting on groundwater resources (Stacey et al., 2010; Vermeulen and Usher, 2005). Post-mining management and predicting the mine water quality after backfilling opencast coal mines therefore becomes imperative. Although most of the trace elements in the Highveld coals (e.g. Sb, As, Cd, Cr, Co, Cu, Pb, Mn, Hg, Mo, Ni, Se, V and $\mathrm{Zn}$ ) are considered toxic (Wagner and Hlatshwayo, 2005), they can also be considered an asset and the prediction of their concentrations in discharging mine water, therefore, can be used to identify metal or semi-metal enrichments. Often, the minimum screening method for the potential contamination of groundwater by mining residues in South Africa is acid-base accounting (Wimberley et al., 2007). This method is particularly employed in Mpumalanga, South Africa, where most of the country's coal reserves are mined (Pinetown et al., 2007). However, this method is purely an indication of potential acidity in mine water with no estimate of leachate chemistry or temporal variation (Younger and Sapsford, 2004). Therefore, the this study focuses on developing a conceptual model based approach to a long term transient numerical quantification method for the evolution of the hydrogeochemistry from decommissioned opencast coal mines. The need for this type of quantification will be highlighted in this study for a decommissioned opencast coal mine near Carolina, Mpumalanga. There, the local regulatory authorities required the quantification of the first flush from this decommissioned opencast mining operation, as well as the ARD potential of its backfill material.

Various authors already studied the prediction of post-mining water quality in underground mines (Appelo and Postma, 2005; Banks, 1994; Gzyl and Banks, 2007; Wolkersdorfer, 1996; Younger, 2000, 2001; Younger and Robins, 2002). Also the flooding scenario of opencast coal mines has been the focus of scientific studies (Ardejani et al., 2003; 2007a; Dumpleton et al., 2001). However, the focus of these studies was either on abandoned, deep underground mines or metal mines. To date, the quantification of the "first flush" phenomenon (Whitehead and Jeffrey, 1995) in backfilled, decommissioned opencast coal mines has not been studied in detail. As the duration and magnitude of the "first flush" in opencast coal mines is assumed to exceed that of underground mines, it is essential to study this effect in more detail. This longer duration is attributed to higher reactive mineral surfaces, slower groundwater flow rates as well as the absence of mine water stratification as it is present in underground collieries (Younger and Sapsford, 2004).

Flooding of rehabilitated opencast mines depends strongly on the type of backfill and how well the backfill has been compacted and the top soils levelled. These before mentioned factors influence the porosity and consequently the recharge rates as a function of the climatic conditions (Hodgson and Krantz, 1998; Reed and Singh, 1986; Singh et al., 1985). In South Africa, the most common practice is concurrent rehabilitation, which is the backfilling and rehabilitation of a previously mined strip, with the overburden of a currently mined strip (Department of Mineral Resources, 2002). This is especially useful in terms of accelerated initial flooding in areas where evaporation supersedes rainfall (Annandale et al., 2001). According to Younger (2000), the flooding time of a mine is one of the factors that controls the duration of its first flush. Consequently, the longer the flooding time of a 
rehabilitated opencast mine, which is controlled by the hydraulic parameters of the backfill and topsoil, the longer the duration of the first flush.

Based on Webster et al. (2006), the type of pit-lake that may form after cessation of mining is determined by the pit location within the landscape as well as groundwater behaviour within the pit. An adapted classification including the recharge volumes (Hodgson and Krantz, 1998) has been used for this study. When the recharge volumes are relatively high, this results in: recharge pits, flow through pits, discharge pits and drainage pits (Fig. 1).

Pits receiving inflow from the surrounding aquifer, filling and flushing backfill void space, as well as discharging seepage from the rehabilitated pit to the aquifer could potentially become flow through pits or discharge pits, if discharge and high levels of evaporation take place on surface (Fig. 1).

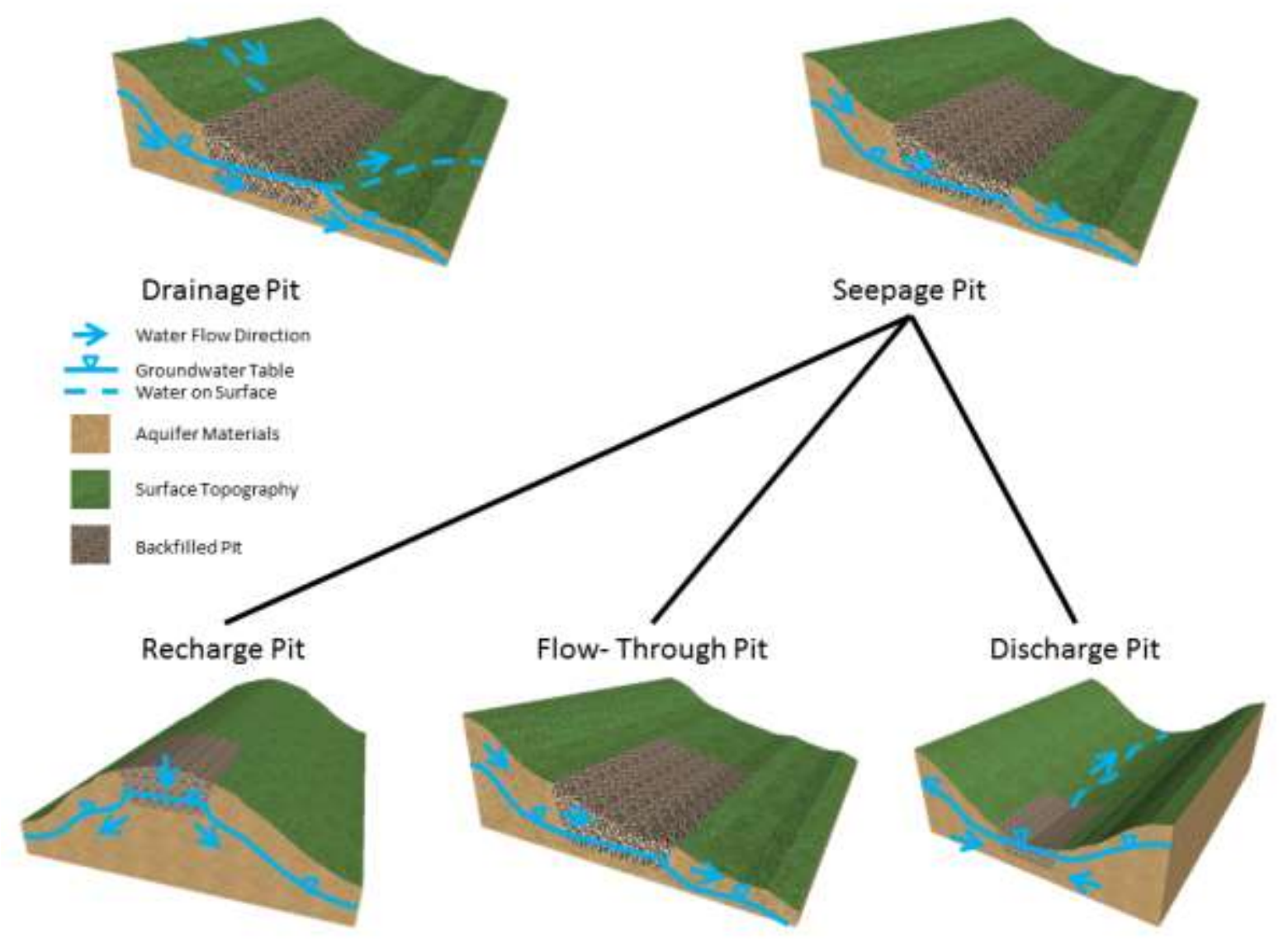

Fig. 1. Potential rehabilitated pit types (modified after Webster et al., 2006).

Relatively accelerated flushing may take place in discharge pits and drainage pits, while slower flushing may take place in seepage pits, recharge pits and flow-through pits. Based on the discharge rates, these scenarios will most likely determine the duration of the first flush from a backfilled opencast mine, similar to underground mines (Gzyl and Banks, 2007).

As the backfill material is highly heterogeneous, its hydraulic conductivity will vary substantially and will generally supersede the hydraulic conductivity of secondary porosity aquifer systems (du Plessis, 2010). It can range between $1 \mathrm{~m} / \mathrm{d}$ and $100 \mathrm{~m} / \mathrm{d}$, which is typically 3 to 4 orders of magnitude higher than that of the surrounding bedrock (Younger and Sapsford, 2004). A study by Hodgson (1984) at a 
rehabilitated colliery near Kriel, Mpumalanga, revealed hydraulic conductivities ranging between 50 and $360 \mathrm{~m} / \mathrm{d}$. Additionally, the higher porosity of the material allows storage coefficients in the material likely to exceed 0.01 and could reach values up to 0.25 (Younger and Sapsford, 2004). Due to this heterogeneous nature of the backfill material, preferential flow zones can occur and will cause increased or decreased flow in the backfill material, thus affecting the residence times (du Plessis, 2010).

Younger and Sapsford (2004) stated that "[essentially] all of the environmental problems associated with opencast coal mining (including the disposal of the lithic wastes to which it gives rise) can be attributed to a single cause: the incompatibility between naturally 'reduced' coal-bearing strata and the strongly oxidising surface / near-surface atmosphere". Therefore, Stumm and Morgan (1996) already called $\mathrm{pH}$ and Eh the "master variables", which regulate the release of contamination from mining wastes to the largest degree. While " $\mathrm{pH}$ (proton activity), which will be determined by the balance between amounts and rates of proton generating reactions and proton consuming (alkalinity generating) reactions", the redox potential "Eh (electron activity) [is] determined by the access to oxidizing species (e.g. oxygen) and [...] reducing species (e.g. organic C)" (Banks, 2004). In a rehabilitated opencast mine, the redox potential is firstly influenced by the rate of diffusion of oxygen through the saturated backfill material, which is substantially lower than that in air (Cussler, 1997). Appelo and Postma (2005) noted that the diffusion of a gas through the soil into the saturated zone depends on the porosity of the material as well as the saturated fraction of the porosity.

An increase in secondary mineral formation is commonly observed in backfill material of opencast mines due to induced oxidising conditions (Younger and Sapsford, 2004). Common secondary minerals identified by Langmuir (1997) include iron rich minerals such as jarosite, sulfate rich minerals including gypsum, melanterite and aluminium rich minerals such as basaluminite. It is predominantly due to these minerals, which dissolve more readily than primary minerals, that the first flush is likely to occur and with it, elevated constituents in groundwater. Elevated concentrations of constituents in mine water may include iron, sulfate, calcium, sodium, potassium, chloride, manganese, aluminium and protons (Geller and Schultze, 2013). Yet, it is also known that hard pans can form on top of mining residues when favourable climatic conditions and physical-mineralogical conditions persist. These hard pans prevent the increased release of potential contaminants, e.g. (Jung, 2002; Rammlmair, 2002).

Various analytical methods have been proposed for the quantification of the first flush from underground mines (Demchak et al., 2001; Frost, 1979; Gzyl and Banks, 2007; Mack et al., 2010). The approaches in these studies relied mainly on the contaminants' time dependent decay rates in mine water fitted with decay curves. By extrapolation, the further course of the contaminants was then predicted. Mack et al. (2010) report that most of the investigated underground mines had an annual contaminant decay rate of approximately two percent per annum. Additionally, Mack et al. (2010) highlighted that due to changing hydrogeological conditions in the mines, the decay rates are likely to be dynamic with higher decay rates in the initial stages of the first flush, equilibrating to lower ones at later stages. Similarly, the temporal concentrations of sulfate and chloride in discharging mine water were fitted with exponential decay curves to confirm the first flush phenomenon (Gzyl and Banks, 2007).

Although these analytical studies focussed on underground mines, much of the data could be used for backfilled opencast mines that also experience flushing, because the geochemical reactions occurring are the same on the working or backfill surface in a flooded underground mine and the backfill surface in an opencast mine. However, due to the nature of the backfill material, the reactive surface 
areas in these mines are much larger than in underground mines. Additionally, the flow environment is variable with unsaturated and saturated flow as well as preferential flow paths present (du Plessis, 2010). This may lead to protracted pyrite oxidation and secondary mineral dissolution. Still, curve fitting in the initial stages of the first flush can be a predictive tool for opencast mines.

A more advanced approach was used by Eriksson and Destouni (1997), Banwart and Malmstrom (2001) and Evans et al. (2003). They parameterised a simplified conceptual geochemical model, which was then translated to a numerical model. It proved that using a conceptual model and simplifying certain parameters, is an effective way to calculate results. The key to this approach is that important parameters such as chemical composition, mineralogy, reactive surface areas, dissolution rate constants, porosity, fluid flow velocity, oxygen availability and fluid to rock ratios are taken into account. This is not the case when idealised decay rate curve fitting is used. When applied to backfilled opencast mines or even flooded underground mines (Chen et al., 1999), numerical models can be used to predict the mine water chemistry reasonably accurately.

Applicability of numerical models to the evolution of mine water geochemistry from opencast mines is further demonstrated by Ardejani et al. (2007b). They constructed a three-dimensional finite volume model to illustrate long term pyrite oxidation and pollutant transport from backfilled opencast mines including various parameters such as porosity of the backfill material, oxygen diffusion into the material, hydraulic head, recharge and hydraulic conductivity. Additionally, they specify changes in sink and source terms which is identical tochanges in aqueous component concentrations as a result of chemical reactions. Their study can therefore be used for source definition and modelling of contaminant transport from opencast mines, though a comparison between computed and observed values to further verify modelled observations is missing.

The study presented here, follows the approach of Eriksson and Destouni (1997), Banwart and Malmstrom (2001) and Evans et al. (2003) in terms of defining the geochemical system using a simplified conceptual model approach. Similar parameters such as mineralogy, leachate chemistry, reactive surface areas, mineral reaction rates and hydraulic properties were defined and modelled using a geochemical model which was then integrated into a numerical flow model similar to that of Ardejani et al. (2007b). Other than in his model, these parameters were calibrated using laboratory testing as well as field and monitoring data and error ranges. Subsequently, the approach followed in the study presented here aims to integrate the approaches of Eriksson and Destouni (1997), Banwart and Malmstrom (2001) and Evans et al. (2003) as well as Ardejani et al. (2007b) to calculate changes in mine water chemistry, while also providing representative prediction, calibrated against initial short-term measured values. Details of this approach are provided in the methods section.

\section{Methods and Site Description}

\subsection{Study Area}

Opencast coal mining in South Africa predominantly takes place in sedimentary Ecca Group rocks of the Karoo Supergroup within the Mpumalanga Province (Hancox and Götz, 2014; Holland et al., 1989; Pinetown et al., 2007). The investigated site mined coal of the Ecca Group's Permian aged Vryheid Formation (Fig. 2), which contains the province's main economic coal seams (Jeffrey, 2005; Johnson et al., 2006; Pinetown et al., 2007). This formation is composed of a lower fluvial-dominated deltaic interval, a middle fluvial interval and a middle fluvial-dominated deltaic interval in the east (Johnson et al., 2006). Therefore, the sedimentary rocks associated with these formations include 
mudstones, siltstones and sandstones (Hancox and Götz, 2014; Johnson et al., 2006; Pinetown et al., 2007; Snyman, 1998). The study site forms part of the Ermelo (Eastern Transvaal) Coalfield, which stretches from Hendrina in the west past Ermelo and Carolina in the east (Glasspool, 2002; Pinetown et al., 2007). In total, from the hanging wall to the foot wall, five coal seams named A Seam to E Seam, are present (Johnson et al., 2006).

The E seam is the deepest coal seam in the Ermelo coalfield and is commonly 0 to $3 \mathrm{~m}$ thick. It is followed by the D seam with a usual thickness of $0.6 \mathrm{~m}$. Thereafter, the $\mathrm{C}$ seam was deposited and is split into two seams: the C Lower seam and the C Upper seam. While the C Lower seam is commonly $1.5 \mathrm{~m}$ thick and contains sandstone partings in its upper section, the C Upper seam is commonly well developed and varies between 0.7 and $4 \mathrm{~m}$ in thickness. Sandstone, mudstone and siltstone partings split the C Upper seam into two to three partings. The B seam is split into two seams, which are called the B Lower seam and the B Upper seam. These seams may coalesce in the south of the Ermelo coalfield and have a combined thickness of 0 to $3 \mathrm{~m}$. The A seam, which has often been eroded, is 0 to $1.5 \mathrm{~m}$ thick. In general, the coal seams of the Ermelo coalfield dip gently to the southwest and are transgressed by dykes and sills (Jeffrey, 2005). Similar to nearly all coal mines in South Africa, the investigated backfill contains the clay minerals illite and kaolinite, the carbonates calcite, dolomite, ankerite and siderite as well as sulfides, quartz and glaukonite. Moreover, the di-sulfides pyrite and marcasite occur in the coal as well as the hanging and foot wall, which is mainly composed of mudrocks (Geldenhuis and Bell, 1998).

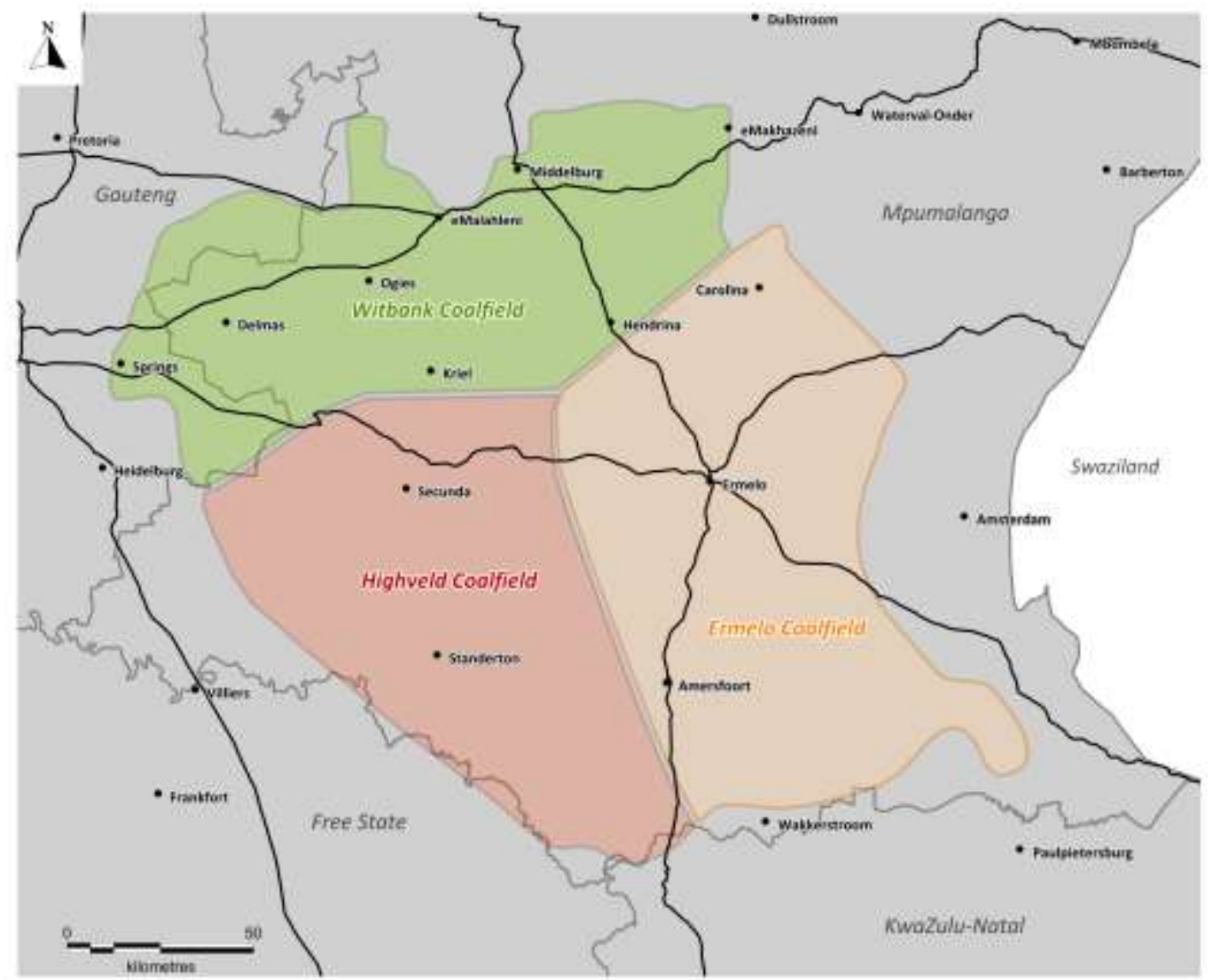

Fig. 2. Distribution of the coalfields in the Mpumalanga Province, South Africa (modified after Snyman, 1998). 
Within the study area, the before mentioned seams were mined by opencast mining, which entails the excavation of overburden material and casting of this material into adjacent mined-out panels (Hartman and Mutmansky, 2002). The typical dimensions of the opencast mine strips are: 30 to $60 \mathrm{~m}$ for the height of the highwall, 23 to $45 \mathrm{~m}$ for the width of the open cut, 60 to $70^{\circ}$ for the slope of the highwall and 35 to $50^{\circ}$ for the slope of the spoils. In smaller scale opencast mines, such as those present in the study area, overburden stripping and mining may be performed by using load and haulage equipment.

Locally, the hydrogeological situation of the Vryheid Formation is controlled by fracture flow, while regional flow is controlled by mafic intrusions in the form of dolerite dykes (Botha et al., 1998). Additionally, due to the poor water storage properties of fractures in these rocks, Botha et al. (1998) state that the storage mechanism in the Karoo aquifers is matrix based. The average hydraulic conductivities of the Karoo lithologies vary between $2.754 \times 10^{-4}$ and $1.740 \times 10^{-8} \mathrm{~m} / \mathrm{s}$ (Botha et al., 1998). Similar results were reported by Kruseman and de Ridder (1994) for fractured rock aquifers, with hydraulic conductivities in the order of $10^{-7}$ to $10^{-5} \mathrm{~m} / \mathrm{s}$. The sedimentary rocks of the Ecca Group have porosities between $2 \%$ and $10 \%$, which could potentially store and release groundwater depending on connectivity of microfractures and pores (Botha et al., 1998).

\subsection{Data collection}

This study uses a conceptual site model including data about the area of the backfilled opencast mine, the pathways (e.g. groundwater flow and mine water discharge) and the receptors (i.e. surface water and the surrounding fractured rock aquifers). To draft the conceptual model, the mineralogical conditions, acid generation capacity and potential leachate quality as well as the site hydrogeology were included. To enhance the conceptual model, monitoring data, additional sampling and previous studies are used (Du Toit, 2010; Huisamen and Naidoo, 2014).

Rock samples from overburden dumps and the backfilled opencast mines (Fig. 2) were collected with a hand auger at depths ranging between 2 and $4 \mathrm{~m}$ and stored in sealed PVC core bags. Their mineralogical composition was determined by whole rock X-ray diffraction (XRD) analysis. Each sample was prepared using a back loading preparation method and the mineral phase abundances quantified using the Rietveld method (Young, 1999).

Acid-base accounting was used as an indicator for the abundance of sulfides and the potential for acid generation in the samples. Samples were analysed for paste $\mathrm{pH}$, total sulfur, acid generation potential, acid neutralisation potential and neutralising potential ratio. These analyses were performed according to the modified Sobek method (Sobek et al., 1978).

As the water levels for all investigated opencast mines are below each pit's base, it was assumed that recharge was the only fluid interaction with the backfill material. Distilled water leach testing was performed on the samples at a 1:4 ratio for $20 \mathrm{~h}$. Subsequent leachates were analysed using ICP-OES for major cations and metals while anion concentrations were determined by ion-chromatography.

Based on the hydrogeological and hydrochemical data obtained from previous studies (Du Toit, 2010; Huisamen and Naidoo, 2014) at the opencast coal mine (Fig. 2), a data analysis was performed and a conceptual model designed (Fig. 3 to Fig. 5). This conceptual model was utilised as a framework for the design of the geochemical model as well as the numerical flow model.

Annual precipitation on site is $736 \mathrm{~mm}$ while evaporation is approximately $1813 \mathrm{~mm}$. Predominant surface drainage on site is a stream flowing from the south to the north. The hydrogeology on site 
consists of weathered and fractured aquifers comprising of sandstones and shales of the Vryheid formation. Hydraulic conductivities of these lithologies vary, depending on the degree of weathering and fracturing, but display an average value of $0.48 \mathrm{~m} / \mathrm{d}$. Water levels on site remain stable with seasonal fluctuations based on monitoring data from 2010 to 2014. Water levels on site are at an average depth of $6.57 \mathrm{~m}$ below ground level and generally mimic the topography. In general, the groundwater level is below the base of the pits and flows away from them towards topographic lows. The only exception to this is Opencast Mine 4 which is located west of the local stream (Fig. 2) and is currently discharging a small amount of mine water, which is considered mainly seepage.

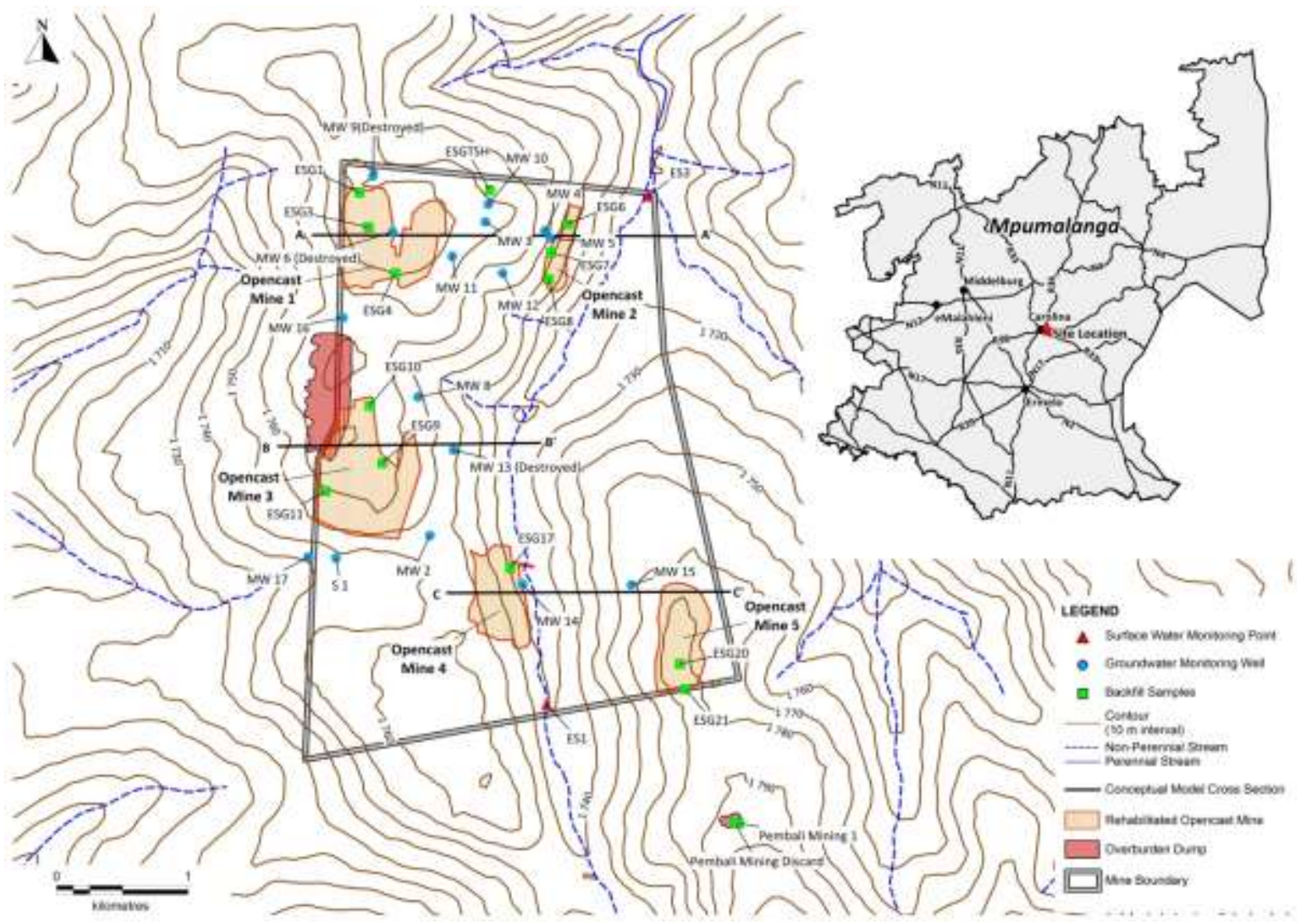

Fig. 3. Geochemical sampling positions of the investigated opencast coal mine and indication of the conceptual model cross-sections.

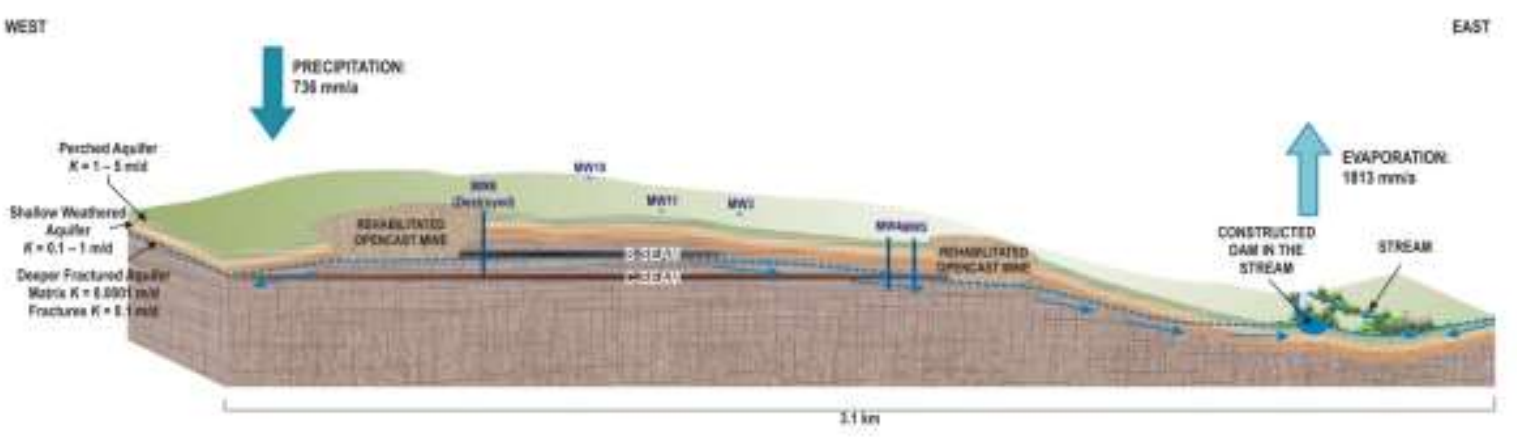

Fig. 4. Conceptual model cross-section A-A' in Fig. 3. 


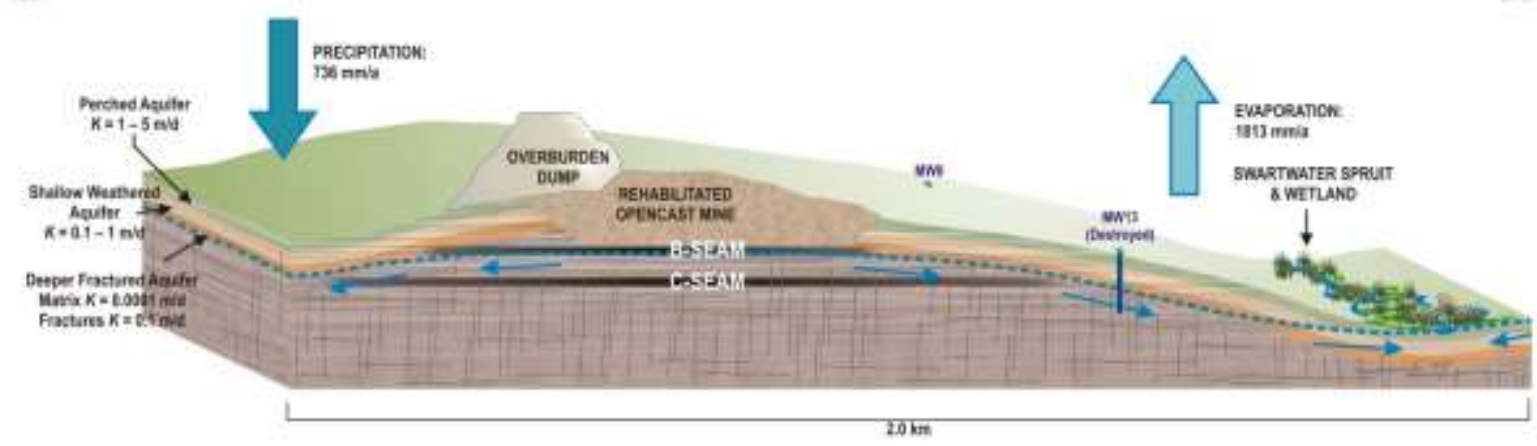

Fig. 5. Conceptual model cross-section B-B' in Fig. 3.

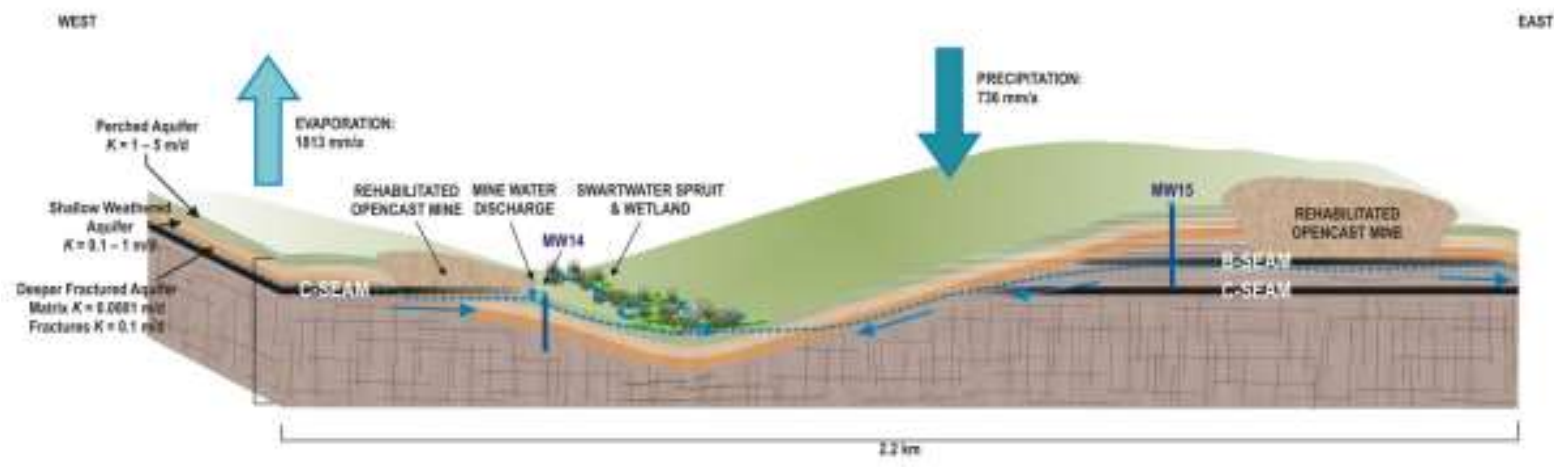

Fig. 6. Conceptual model cross-section $\mathrm{C}-\mathrm{C}^{\prime}$ in Fig. 3.

\subsection{Geochemical Model}

To construct the geochemical model, "The Geochemist's Workbench" V9 (GWB) was used as the graphical user interface (Bethke, 2008). This software can define the dynamic geochemical system by using mineral abundances, water qualities, mineral reaction rates and mineral reactive surface areas. Mineral abundances were calculated based on the XRD results and their average weight percentage calculated along with the associated standard error. Subsequently, the standard error was used to determine the upper and lower limits for the weight percentage of the specific mineral.

Mineral reaction rates were obtained from literature sources (Gautier et al., 2001; Gudbrandsson et al., 2014; Hersman et al., 1995; Huertas et al., 1999; Jeschke et al., 2001; Malmström et al., 2006; Marty et al., 2015; Oelkers and Schott, 1998; Oelkers et al., 2008). Additionally, the grain sizes of minerals in the backfill material, was used to calculate reactive surface areas (Gautier et al., 2001). This calculation is based on mineral densities (Klein et al., 2008) as well as the volume of grains in the sample, assuming that the grains are spherical and most of the grain will be available for reaction with fluids.

When specific minerals were not identified during analysis, the abundance of these minerals was estimated based on existing data. Abundances of sulfide minerals were estimated based on the studies by Glasspool (2002), Pinetown and Boer (2006) and Pinetown et al. (2007). Additional to this, acidbase accounting along with mine water analyses of discharging mine water in the area was used to estimate the sulfide mineral abundances. Rate constants of these minerals were obtained from the study by Malmström et al. (2006), with reactive surface areas calibrated using the geochemical model. 
Once the mineral assemblage, reaction rates and reactive surface areas were defined, the laboratory leach testing scenario was simulated to calibrate the mineral assemblage. This was done by simulating the distilled water leach test procedure with the same time duration and fluid to rock ratio as explained in earlier sections. The system was defined to be open to oxygen, assuming an oxygen fugacity of 0.21 . Additionally, the leach test results were also averaged for each constituent analysed and a standard error calculated. This provided the upper and lower boundaries for the simulated concentration of each constituent. The final simulated concentrations were then compared to the final leach test concentrations. If the concentrations correlated well, the mineral assemblage was considered to be calibrated. When results were dissimilar, the input parameters were revised and adjusted.

The calibrated mineral assemblage was used in the kinetic geochemical model to simulate the chemical reactions in the backfilled opencast mine and the resulting leachate composition. The fluid to rock ratio of this simulation was calculated based on an idealised daily recharge rate. This calculation provided a volume of water relative to the unsaturated pore volume of the backfill material in the pit. Additionally, oxygen fugacity was assumed to be multiple orders of magnitude lower than in an open system (Appelo and Postma, 2005). Further to this, additional water is added to the simulated system at the calculated idealised recharge rate per day. This simulates the volume of water the assemblage reacts with over time to produce the first flush.

\subsection{Integration with a Numerical Flow Model - Transient Chemical Calibration}

Using the above described temporal geochemical results, a numerical flow and transport model in MODFLOW was constructed with the GMS 10 pre-processor. After the calculated transient sulfate concentration was specified, the developing contaminant plume was modelled and calibrated against monitoring data. In an iterative attempt, the numerical model was revised and the transport model adjusted using recharge rates and the available monitoring data until the model produced representative results for the monitoring period. Finally, this model served to determine the potential future contaminant loads from the opencast coal mine.

\section{Results and Discussion}

\subsection{Geochemical Model}

The XRD analyses show that quartz, muscovite, k-feldspar, kaolinite, plagioclase, hematite and smectite are abundant in the backfill material (Table 1). Additionally, fragments of coal were identified in the backfill material on site. Secondary minerals observed in the backfilled areas and around the discharge point were assumed to be gypsum. Based on the leaching test results, the geological setting of the opencast mine (Geldenhuis and Bell, 1998; Glasspool, 2002; Pinetown and Boer, 2006; Pinetown et al., 2007) and field observations, pyrite is also present. These minerals were reacted with distilled water as leaching fluid using the kinetic reactant function of GWB as described earlier. The model was then calibrated against the results of the leaching tests (Table 2) using a $20 \mathrm{~h}$ reaction time in a 1:4 rock to water ratio and an oxygen fugacity of 0.21 (open system). All leaching test analyses were performed according to SANAS accredited standards and included 37 elements and physical-chemical parameters.

In general, the model was considered calibrated when the model concentrations were within the range of the standard error of the analysed constituent (Fig. 6), favouring results closer to the mean 
concentrations. In cases, where the model concentration of a constituent did not fall within that range, the mineral abundances, reactive surface areas and rate constants were adjusted by no more than an order of magnitude to achieve the analysed concentrations. The results of the modelling procedure are in good accordance with the analysed results (Fig. 7).

Table 1. Results of the XRD of five backfill samples from the opencast mine.

\begin{tabular}{llllll}
\hline $\begin{array}{l}\text { Mineral Phase } \\
\text { Based on Analysis } \\
\text { Data }\end{array}$ & $\begin{array}{l}\text { Mean, } \\
\text { mass } \%\end{array}$ & $\begin{array}{l}\text { Standard } \\
\text { Deviation, } \\
\text { mass } \%\end{array}$ & $\begin{array}{l}\text { Standard Error } \\
\text { of mean mass } \\
\%\end{array}$ & $\begin{array}{l}\text { Initial Reaction } \\
\text { Rate Constant } \\
\left(\mathrm{mol} \cdot \mathrm{cm}^{-2} \cdot \mathrm{s}^{-1}\right)\end{array}$ & $\begin{array}{l}\text { Initial Reactive } \\
\text { Surface Area } \\
\left(\mathrm{cm}^{2} \cdot \mathrm{g}^{-1}\right)^{\#}\end{array}$ \\
\hline Hematite & 0.77 & 0.46 & 0.19 & $5 \times 10^{-11 \mathrm{a}}$ & 57 \\
Kaolinite & 16.56 & 8.32 & 3.39 & $1 \times 10^{-17 \mathrm{~b}}$ & 58 \\
K-Feldspar & 10.87 & 2.57 & 1.05 & $1.7 \times 10^{-17 \mathrm{c}}$ & 58.5 \\
Muscovite & 6.01 & 1.59 & 0.65 & $2.9 \times 10^{-15 \mathrm{~d}}$ & 53 \\
Plagioclase & 2.03 & 4.53 & 1.85 & $1.0 \times 10^{-16 \mathrm{e}}$ & 55 \\
Quartz & 45.25 & 11.15 & 4.55 & $5.0 \times 10^{-14 \mathrm{f}}$ & 22.5 \\
Smectite & 36.22 & 2.26 & 0.92 & $3.0 \times 10^{-15 \mathrm{~g}}$ & 60 \\
Pyrite & $0.03^{*}$ & n.a. & n.a. & $2.8 \times 10^{-12 \mathrm{~h}}$ & 104 \\
Gypsum & $0.05^{*}$ & n.a. & n.a. & $1.3 \times 10^{-04 \mathrm{i}}$ & 26 \\
\hline
\end{tabular}

${ }^{\mathrm{a}}$ Hersman et al. (1995); ${ }^{\mathrm{b}}$ Huertas et al. (1999); ${ }^{\mathrm{c}}$ (Oelkers and Schott, 1998); ${ }^{\mathrm{d}}$ Oelkers et al. (2008); ${ }^{\mathrm{e}}$ Gudbrandsson et al. (2014); ${ }^{\mathrm{f}}$ Gautier et al. (2001); ${ }^{\mathrm{g}}$ Marty et al. (2015); ${ }^{\mathrm{h}}$ Malmström et al. (2006); ${ }^{\mathrm{i}}$ Jeschke et al. (2001); " Estimated based on field observations, acid-base accounting, grain sizes and

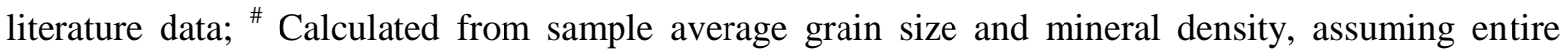
surface is available for reaction (Brantley, 1998; Gautier et al., 2001; White and Brantley, 2003); n.a.: not applicable.

Table 2. Summary of analysed leachate compositions from distilled water leaching tests performed on five backfill material samples; TDS: Total dissolved solids, Total alkalinity in $\mathrm{CaCO}_{3}$ equivalents, $n=5$.

\begin{tabular}{lllll}
\hline Chemical Constituent in mg/L & $\begin{array}{l}\text { Mean } \\
\text { Concentration, } \\
\mathrm{mg} / \mathrm{L}\end{array}$ & $\begin{array}{l}\text { Standard } \\
\text { Deviation }\end{array}$ & Standard Error & $\begin{array}{l}\text { Range of } \\
\text { concentrations, } \\
\mathrm{mg} / \mathrm{L}\end{array}$ \\
\hline $\mathrm{Al}$ & 0.23 & 0.42 & 0.17 & $0-1.04$ \\
$\mathrm{Ca}$ & 9.17 & 14.30 & 5.84 & $0-38$ \\
$\mathrm{Fe}$ & 0.14 & 0.30 & 0.12 & $0-0.75$ \\
$\mathrm{~K}$ & 3.55 & 2.22 & 0.91 & $0-6.1$ \\
$\mathrm{Mg}$ & 4.67 & 4.89 & 1.99 & $0-14$ \\
$\mathrm{Mn}$ & 1.38 & 3.08 & 1.26 & $0.04-7.66$ \\
$\mathrm{Na}$ & 2.67 & 1.37 & 0.56 & $0-4$ \\
$\mathrm{Si}$ & 4.93 & 2.29 & 0.94 & $3.57-9.5$ \\
$\mathrm{TDS}$ & 90.8 & 115.5 & 47.2 & $0-322$ \\
$\mathrm{Cl}$ & 1.0 & 2.5 & 1.0 & $0-6$ \\
$\mathrm{SO} \mathrm{N}_{4}$ & 33.4 & 70.3 & 28.7 & $9-203$ \\
$\mathrm{NO}_{3}$ & 1.1 & 1.0 & 0.4 & $0-0.5$ \\
$\mathrm{Total}_{\mathrm{p}}$ Alkalinity in $\mathrm{mg} / \mathrm{L}$ & 0.00 & & & \\
$\mathrm{pH}$ & 4.92 & 0.75 & 0.30 & $4.4-6.4$ \\
$\mathrm{EC}, \mathrm{mS} / \mathrm{m}$ & 14.57 & 14.28 & 5.83 & $4-42.9$ \\
Temperature in ${ }^{\circ} \mathrm{C}$ & 25 & & & \\
\hline
\end{tabular}




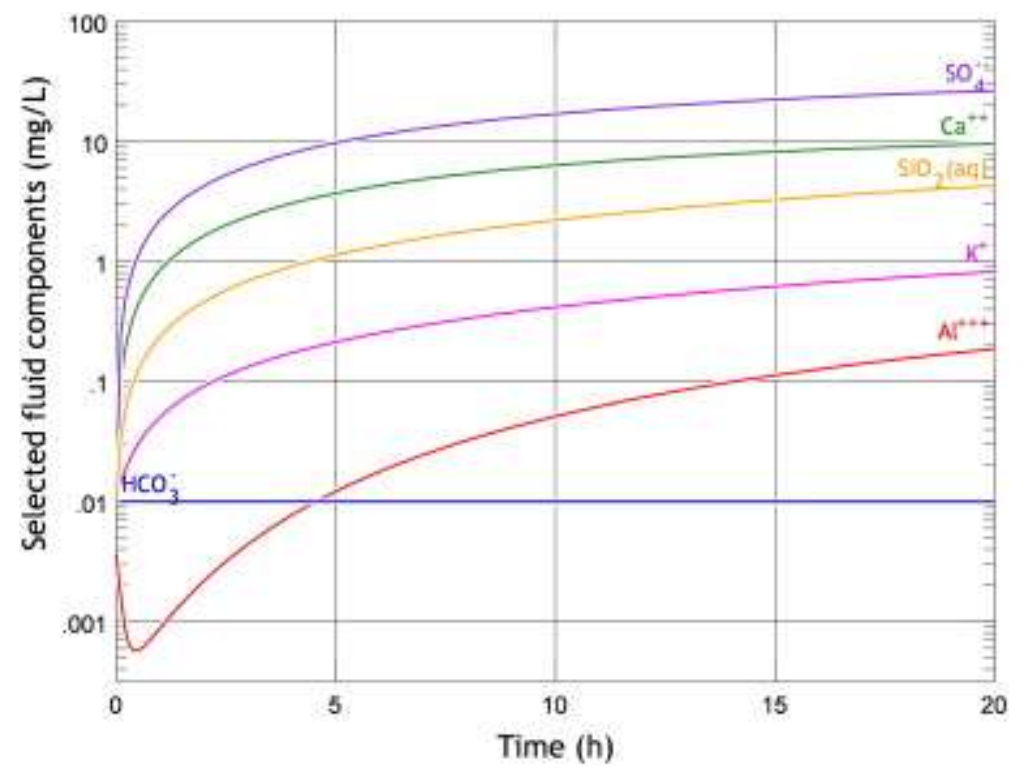

Fig. 7. Simulated concentrations in the geochemical model (details in the text).

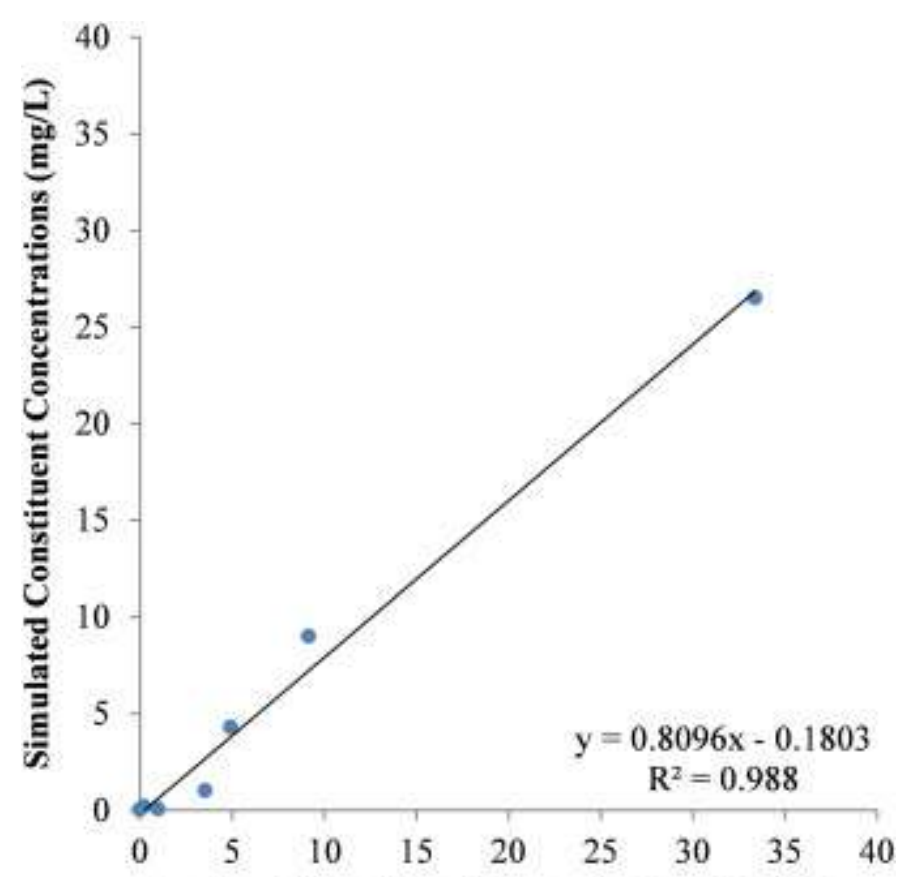

Analysed Constituent Concentrations (mg/L)

Fig. 8. Calibration graph of analysis concentrations vs. simulated concentrations in the geochemical model.

After calibration of the model, the natural conditions expected in the opencast coal mine were modelled. This was performed by specifying the calibrated mineral assemblage and calculating the expected fluid to rock ratio in the backfilled opencast mine, as well as the flow volumes through the material over time. Assuming an initial recharge of $20 \%$ in the backfilled pits (Hodgson and Krantz, 1998), a fluid to rock ratio of approximately $1 \times 10^{-5}: 1$ was calculated, assuming a porosity of $30 \%$. Using this methodology, the reaction was simulated for the duration of the period for which groundwater monitoring data existed for the site. 


\subsection{Integration with the Numerical Flow Model}

After simulating the backfill material-rain interaction, the results were integrated into the numerical flow model. This was done by specifying the calculated transient sulfate concentration obtained from the geochemical model as a specified concentration in the mass transport model with the code MT3DMS. Once the simulation was completed, a transient calibration graph with error range of $20 \mathrm{mg} / \mathrm{L}$ was constructed to determine how well the simulated sulfate concentrations compare to monitoring data (Fig. 8 and Fig. 9). The selection of the $20 \mathrm{mg} / \mathrm{L}$ error margin is based on a $10 \%$ error range of the South African water quality standard of $200 \mathrm{mg} / \mathrm{L}$ for sulfate. Most of the simulation results are within this specified error range and the general trend of sulfate release. General contaminant transport and decay of sulfate concentrations can therefore be simulated within the selected error margins.

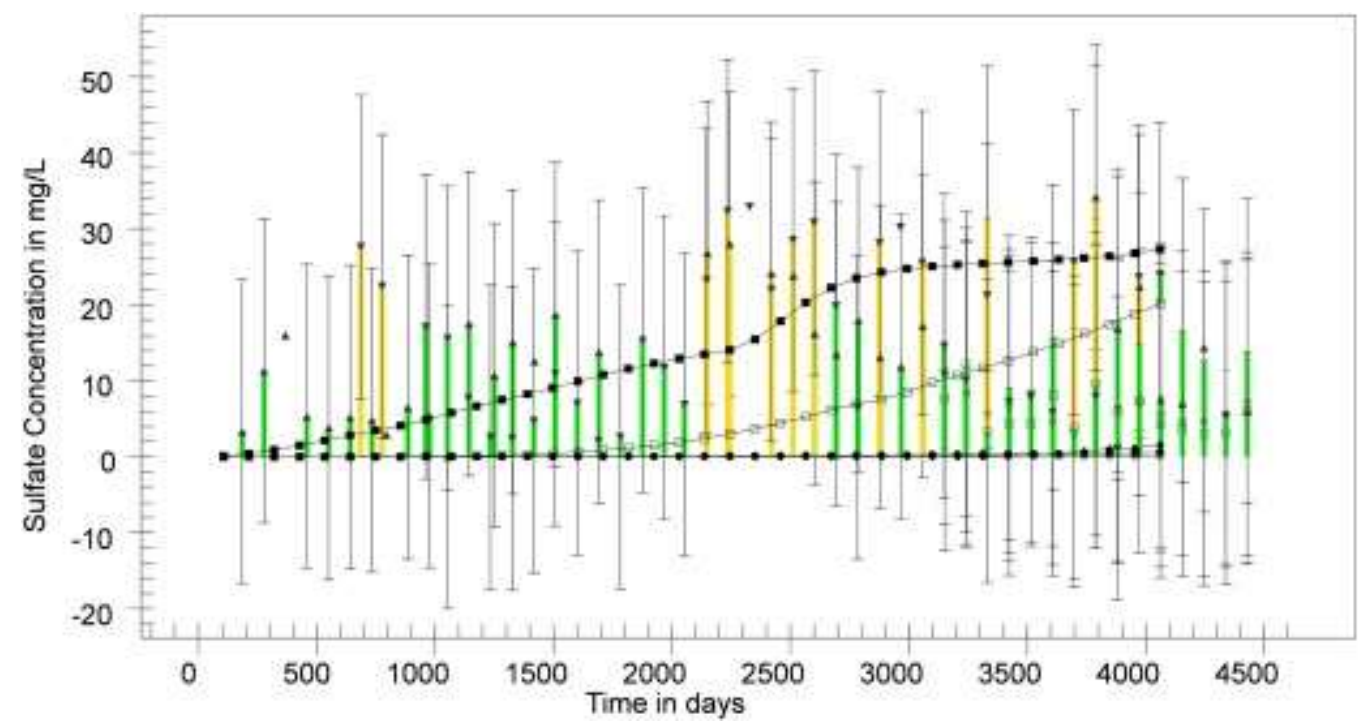

Fig. 9. Simulated concentrations in the numerical flow model calibrated against monitoring data for monitoring wells MW2, MW8, MW14, MW15 and MW17; dotted lines represent calculated concentrations with triangular data points representing monitored sulfate concentrations; error bars represent a $20 \mathrm{mg} / \mathrm{L}$ error range. 

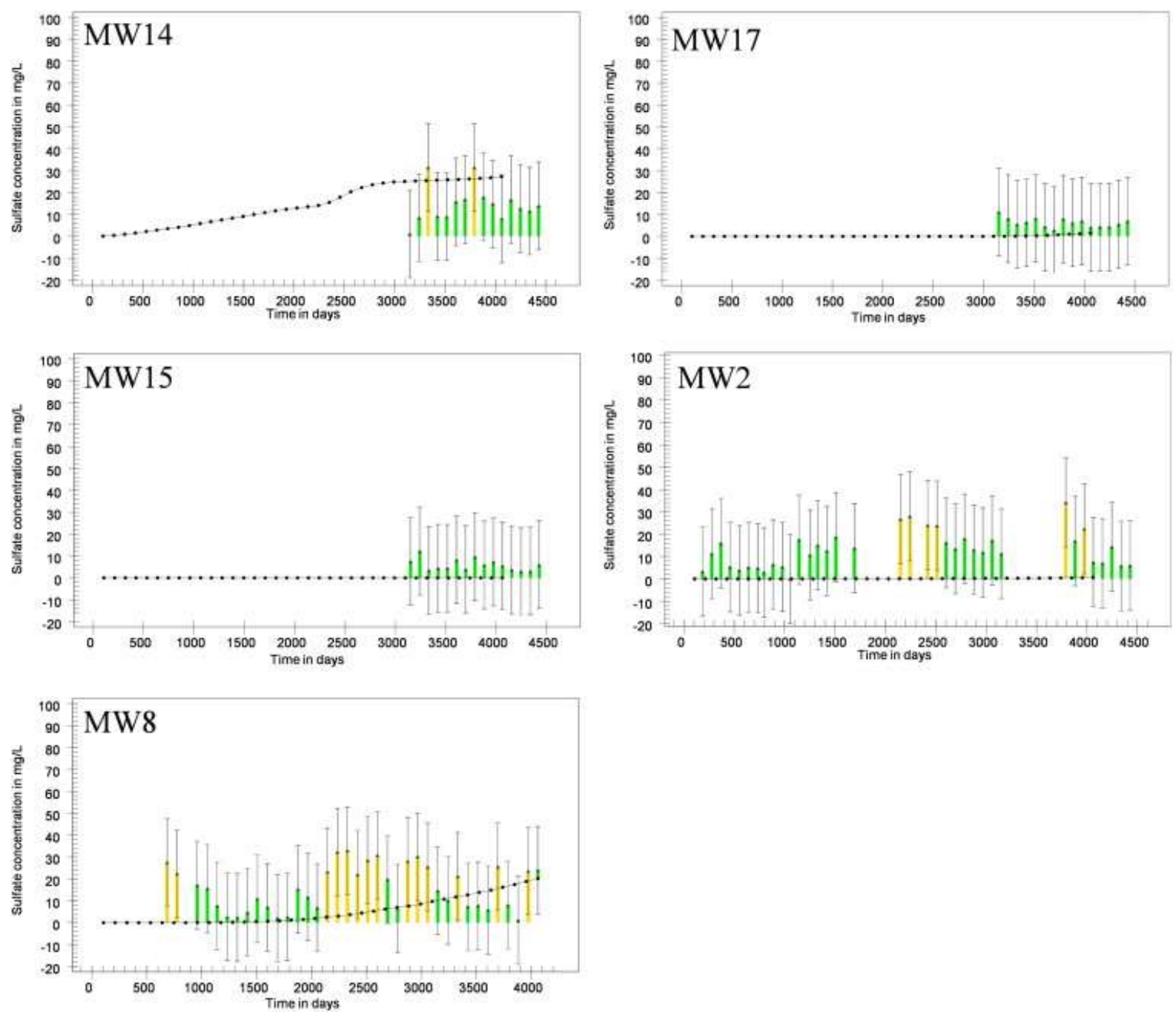

Fig. 10. Simulated sulfate concentrations in the numerical flow model calibrated against monitoring data for monitoring wells MW2, MW8, MW14, MW15 and MW17; dotted lines represent calculated concentrations with triangular data points representing monitored sulfate concentrations; error bars represent a $20 \mathrm{mg} / \mathrm{L}$ error range.

\section{Conclusions}

In this study it could be shown that the prediction of the mine water quality in flooded and backfilled opencast mines is possible. The results obtained from the described methodology are in good accordance with monitoring data for the investigated site. This indicates that the numerical method can successfully be used to make improved estimates of long term mine water quality evolution from opencast mines within order of magnitude accuracies. This makes the proposed transport modelling method especially applicable to the estimation of the duration of the first flush. As the duration of persistence of contamination in mine water is often a concern in closure planning, this approach will prove useful. An estimate can be given in terms of the time and expenditure that mining companies will likely have to invest in post-closure treatment and maintenance. After this time has passed, backfilled opencast mines are likely to transform into reservoirs of potentially potable water for supply to various industries and even as drinking water. This prospect could turn decommissioned collieries into viable investments for the "mining" and sale of much needed water, effectively re-using the decommissioned mine. In addition to the possible sale of water, the extraction of metals from 
mine water could also prove to be a viable investment for the duration of the first flush, further augmenting the idea of "mining water". Although promising results have been achieved with this approach, further refinement will be needed. Additional studies will include the role of microbiology in ARD generation at investigated sites, as well as incorporating transient meteorological data into the modelling process, to improve the modelling results. A potential further investigation will be performed in terms of the viability of extracting metals from discharging mine water for reclamation.

\section{Acknowledgements}

A. Huisamen expresses sincere gratitude to Gideon Du Toit as well as Van der Ahee Coetsee for continued support in the development of this methodology. The personnel of the anonymous mine site are gratefully acknowledged for access to the site and permission to sample, as well as the data generously supplied for this study. Geo Pollution Technologies - Gauteng (Pty) Ltd is gratefully acknowledged for additional funding of this research.

\section{References}

Annandale, J.G., Jovanovic, N.Z., Rethman, N.F.G., Pretorius, J.J.B., Tanner, P.D., 2001 . Gypsiferous mine water use in irrigation on rehabilitated open-cast mine land: Crop Production, soil water and salt balance. Ecol. Eng. 17, 153-164.

Appelo, C.A.J., Postma, D., 2005. Geochemistry, groundwater \& pollution, 2nd ed. Balkema, Leiden.

Ardejani, F.D., Singh, R., Baafi, E., Shafaei, S.Z., Aryafar, A., 2007a. Prediction of post-mining Groundwater Recovery Pattern in an unconfined Aquifer to predict Opencast Mine Backfill Settlement. Mako Edizioni, Cagliari.

Ardejani, F.D., Singh, R., Marandi, R., Baafi, E., 2007b. A three dimensional Finite Volume Model for Acid Mine Drainage Simulation in Opencast Mine Backfill. Mako Edizioni, Cagliari.

Ardejani, F.D., Singh, R.N., Baafi, E., Porter, I., 2003. A Finite Element Model to: 2. Simulate Groundwater Rebound Problems in Backfilled Open Cut Mines. Mine Water Environ. 22, 39-44.

Banks, D., 1994. The Abandonment of the Killingdal Sulphide Mine, Norway: a Saga of Acid Mine Drainage and Radioactive Waste Disposal. Mine Water Environ. 13, 35-48.

Banks, D., 2004. Geochemical Processes controlling Minewater Pollution, Conference Papers. Umweltbundesamt, Wien, 17-44.Banwart, S.A., Malmstrom, M.E., 2001. Hydrochemical modelling for preliminary assessment of mine water pollution. J. Geochem. Explor. 74, 73-79.

Bethke, C.M., 2008. Geochemical and Biogeochemical Reaction Modeling. Cambridge University Press, New York.

Botha, J.F., Verwey, J.P., van der Voort, I., Vivier, J.J.P., Buys, J., Colliston, W.P., Loock, J.C., 1998. Karoo Aquifers - Their Geology, Geometry and Physical Properties, Water Research Commission, 487/1/98. Water Research Commission, South Africa. 
Brantley, S.L., 1998. Surface area and porosity of primary silicate minerals, Goldschmidt Conference Toulouse, pp. 229-230.

Chen, M., Soulsby, C., Younger, P.L., 1999. Modelling the evolution of minewater pollution at Polkemmet Colliery, Almond catchment, Scotland. Q. J. Eng. Geol. 32, 351-362.

Cussler, E.L., 1997. Diffusion: Mass Transfer in Fluid Systems, 2nd ed. Cambridge University Press, New York.

Demchak, J., Skousen, J., McDonald, L., 2001. Water quality improvements over time and longevity of acid mine discharges from underground mines in northern West Virginia, 18th Annual National Meeting of the American Society of Mining and Reclamation, Albuquerque, pp. 174-182.

Department of Mineral Resources, S.A., 2002. Mineral and Petroleum Resources Development Act of South Africa, in: Department of Mineral Resources, S.A. (Ed.). Department of Mineral Resources, South Africa, South Africa.

du Plessis, J.L., 2010. Decant Calculations and Groundwater - Surface Water Interaction in an Opencast Coal Mining Environment, Institute for Groundwater Studies. University of the Free State, Free State, South Africa, p. 198.

Du Toit, G.J., 2010. Groundwater Modelling Report For The C-Mine Colliery, GeEast-10-130. Geo Pollution Technologies, Pretoria, South Africa.

Dumpleton, S., Robins, N., Walker, J., Merrin, P., 2001. Mine water rebound in South Nottinghamshire: risk evaluation using 3-D visualization and predictive modelling. Q. J. Eng. Geol. Hydroge. 34, 307-319.

Eriksson, N., Destouni, G., 1997. Combined effects of dissolution kinetics, secondary mineral precipitation, and preferential flow on copper leaching from mining waste rock. Water Resour. Res. 33, 471-483.

Evans, K.A., Gandy, C.J., Banwart, S.A., 2003. Mineralogical, numerical and analytical studies of the coupled oxidation of pyrite and coal. Mineral. Mag. 67, 381-398.

Frost, R.C., 1979. Evaluation of the rate of decrease in the iron content of water pumped from a flooded shaft mine in County Durham, England. J. Hydrol. 40, 101-111.

Gautier, J.M., Oelkers, E.H., Schott, J., 2001. Are quartz dissolution rates proportional to B.E.T. surface areas? Geochim. Cosmochim. Acta 65, 1059-1070.

Geldenhuis, S., Bell, F.G., 1998. Acid mine drainage at a coal mine in the eastern Transvaal, South Africa. Environ. Geol. 34, 234-242.

Geller, W., Schultze, M., 2013. Remediation and management of acidified pit lakes and outflowing waters, in: Geller, W., Schultze, M., Kleinmann, R., Wolkersdorfer, C. (Eds.), Acidic Pit Lakes: The Legacy of Coal and Metal Surface Mines. Springer, Berlin, Heidelberg, pp. 225-264. 
Glasspool, I.J., 2002. Hypautochthonous-allochthonous coal deposition in the Permian, South African, Witbank Basin No. 2 seam; a combined approach using sedimentology, coal petrology and palaeontology. Int. J. Coal Geol. 53, 81-135.

Gudbrandsson, S., Wolff-Boenisch, D., Gislason, S.R., Oelkers, E.H., 2014. Experimental determination of plagioclase dissolution rates as a function of its composition and $\mathrm{pH}$ at $22^{\circ} \mathrm{C}$. Geochim. Cosmochim. Acta 139, 154-172.

Gzyl, G., Banks, D., 2007. Verification of the "first flush" phenomenon in mine water from coal mines in the Upper Silesian Coal Basin, Poland. J. Contam. Hydrol. 92, 66-86.

Hancox, P.J., Götz, A.E., 2014. South Africa's coalfields - A 2014 perspective. Int. J. Coal Geol. $132,170-254$.

Hartman, H.L., Mutmansky, J.M., 2002. Introductory Mining Engineering, 2nd ed. Wiley \& Sons, Hoboken.

Hersman, L., Lloyd, T., Sposito, G., 1995. Siderophore-promoted dissolution of hematite. Geochim. Cosmochim. Acta 59, 3327-3330.

Hodgson, F.D.I., 1984. Installation and evaluation of a groundwater monitoring system in the strip mining area at Kriel colliery. Institute for Groundwater Studies, South Africa.

Hodgson, F.D.I., Krantz, R.M., 1998. Groundwater Quality Deterioration in the Olifants River Catchment above the Loskop Dam with Specialized Investigation in the Witbank Dam SubCatchment, Water Research Commission Report, 291/1/98. Water Research Commission, South Africa.

Holland, M.J., Cadle, A.B., Pinheiro, R., Falcon, R.M.S., 1989. Depositional environments and coal petrography of the Permian Karoo Sequence: Witbank Coalfield, South Africa. Int. J. Coal Geol. 11, 143-169.

Huertas, F.J., Chou, L., Wollast, R., 1999. Mechanism of kaolinite dissolution at room temperature and pressure Part II: kinetic study. Geochim. Cosmochim. Acta 63, 3261-3275.

Huisamen, A., Naidoo, V., 2014. Groundwater Report For Long Term Groundwater Management At C-Mine Colliery, Carolina, Mpumalanga, GeoEast-14-438. Geo Pollution Technologies, Pretoria, South Africa.

Jeffrey, L.S., 2005. Characterization of the coal resources of South Africa. J. S. Afr. Inst. Min. Metall., 95-102.

Jeschke, A.A., Vosbeck, K., Dreybrodt, W., 2001. Surface controlled dissolution rates of gypsum in aqueous solutions exhibit nonlinear dissolution kinetics. Geochim. Cosmochim. Acta 65, 27-34.

Johnson, M.R., van Vuuren, C.J., Visser, J.N.J., Cole, D.J., Wickens, H.d.V., Christie, A.D.M., Roberts, D.L., Brandl, G.L., 2006. Sedimentary Rocks of the Karoo Supergroup, in: Johnson, M.R., Annhaeusser, C.R., Thomas, R.J. (Eds.), The Geology of South Africa. The Geological Society of South Africa, South Africa, pp. 9-56. 
Jung, H.G., 2002. Sekundäre Prozesse in Bergbauhalden und Aufbereitungsabgängen Steuerung von Stoffmobilität und Krustenbildung. Philipps-Universität Marburg, Marburg, p. 202.

Klein, C., Dutrow, B., Dana, J.D., 2008. The 23rd edition of the manual of mineral science: (after James D. Dana). J. Wiley, Hoboken.

Kruseman, G.P., de Ridder, N.A., 1994. Analysis and Evaluation of Pumping Test Data, 2nd ed. International Institute for Land Reclamation and Improvement, Wageningen, The Netherlands.

Langmuir, D., 1997. Aqueous Environmental Geochemistry. Prentice-Hall, New Jersey.

Mack, B., McDonald, L.M., Skousen, J., 2010. Acidity decay of above-drainage underground mines in West Virginia. J. Environ. Qual. 39, 1043-1050.

Malmström, M.E., Gleisner, M., Herbert, R.B., 2006. Element discharge from pyritic mine tailings at limited oxygen availability in column experiments. Appl. Geochem. 21, 184-202.

Marty, N.C.M., Claret, F., Lassin, A., Tremosa, J., Blanc, P., Madé, B., Giffaut, E., Cochepin, B., Tournassat, C., 2015. A database of dissolution and precipitation rates for clay-rocks minerals. Appl. Geochem. 55, 108-118.

Oelkers, E.H., Schott, J., 1998. Does organic acid adsorption affect alkali-feldspar dissolution rates? Chem. Geol. 151, 235-245.

Oelkers, E.H., Schott, J., Gauthier, J.-M., Herrero-Roncal, T., 2008. An experimental study of the dissolution mechanism and rates of muscovite. Geochim. Cosmochim. Acta 72, 4948-4961.

Pinetown, K.L., Boer, R.H., 2006. A quantitative evaluation of the modal distribution of minerals in coal deposits in the Highveld area and the associated impact on the generation of acid and neutral mine drainage, WRC Report, 1264/1/06. Water Research Commission, Pretoria, p. 92.

Pinetown, K.L., Ward, C.R., van der Westhuizen, W.A., 2007. Quantitative evaluation of minerals in coal deposits in the Witbank and Highveld Coalfields, and the potential impact on acid mine drainage. Int. J. Coal Geol. 70, 166-183.

Rammlmair, D., 2002. Hard pan formation on mining residuals, in: Merkel, B.J., Planer-Friedrich, B., Wolkersdorfer, C. (Eds.), Uranium in the Aquatic Environment. Springer, Heidelberg, Germany, pp. 177-186.

Reed, S.M., Singh, R.N., 1986. Groundwater Recovery Problems Associated with Opencast Mine Backfills in the United Kingdom. Int. J. Mine Water 5, 47-73.

Singh, R.N., Denby, B., Reed, S.M., 1985. The Effect of Groundwater re-establishment on the Settlement of Opencast Mine Backfills in the United Kingdom. Proceedings, 2nd International Mine Water Association Congress 2, 803-816.

Snyman, C.P., 1998. Coal, in: Wilson, M.G.C., Anhaeusser, C.R. (Eds.), The Mineral Resources of South Africa, 6th ed. Council for Geoscience, Pretoria. 
Sobek, A.A., Schuller, W.A., Freeman, J.R., Smith, R.M., 1978. Field and laboratory methods applicable to overburdens and minesoils. USEPA, Cincinnati, Ohio.

Stacey, J., Naude, A., Hermanus, M., Frankel, P., 2010. The socio-economic aspects of mine closure and sustainable development: literature overview and lessons for the socio-economic aspects of closure - Report 1. J. S. Afr. Inst. Min. Metall. 110, 379-394.

Stumm, W., Morgan, J.J., 1996. Aquatic Chemistry - Chemical Equilibria and Rates in Natural Waters, 3rd ed. Wiley \& Sons, New York.

Vermeulen, P.D., Usher, B.H., 2005. Sulphate generation in South African underground and opencast collieries. Env. Geol. 49, 552-569.

Wagner, N.J., Hlatshwayo, B., 2005. The occurrence of potentially hazardous trace elements in five Highveld coals, South Africa. Int. J. Coal Geol. 63, 228-246.

Webster, K.E., Bowser, C.J., Anderson, M.P., Lenters, D.J., 2006. Understanding the lakegroundwater system: just follow the water, in: Magnuson, J.J., Kratz, T.K., Benson, B.J. (Eds.), Longterm dynamics of lakes in the landscape. Oxford University Press, Oxford, pp. 19-48.

White, A.F., Brantley, S.L., 2003. The effect of time on the weathering of silicate minerals: why do weathering rates differ in the laboratory and field? Chem. Geol. 202, 479-506.

Whitehead, P., Jeffrey, H., 1995. Heavy metals from acid mine drainage - impacts and modelling strategies, in: Petts, G.E. (Ed.), Man's Influence on Freshwater Ecosystems and Water Use. International Association of Hydrological Sciences, Wallingford, pp. 55-56.

Wimberley, F., Jordaan, J., Pulles, W., 2007. Best Practice Guideline A2: Water Management For Mine Residue Deposits. Department of Water Affairs and Forestry (DWAF), South Africa.

Wolkersdorfer, C., 1996. Hydrogeochemische Verhältnisse im Flutungswasser eines Uranbergwerks Die Lagerstätte Niederschlema/Alberoda. Clausthaler Geowissenschaftliche Dissertationen 50, 1-216.

Young, R.A., 1999. The Rietveld Method. Oxford University Press, Oxford.

Younger, P.L., 2000. Predicting temporal changes in total iron concentrations in groundwaters flowing from abandoned deep mines: a first approximation. J. Contam. Hydrol. 44, 47-69.

Younger, P.L., 2001. Mine water pollution in Scotland: nature, extent and preventative strategies. Sci. Total Environ. 265, 309-326.

Younger, P.L., Robins, N.S., 2002. Challenges in the characterization and prediction of the hydrogeology and geochemistry of mined ground. Spec. Publ. - Geol. Soc. London 198, 1-16.

Younger, P.L., Sapsford, D.J., 2004. Evaluating the potential impact of opencast coal mining on water quality (Groundwater Regulations 1998) An assessment framework for Scotland. Scottish Environmental Protection Agency, Scotland, pp. 1-75. 